УДК 786.2+78.03+78.085.21

\title{
И. Тимченко-Быхун
}

\section{ПЕРВАЯ ПРОГРАММНАЯ МИНИАТЮРА М. ГЛИНКИ «ПРОЩАЛЬНЫЙ ВАЛЬС»: АВТОБИОГРАФИЧЕСКИЕ СМЫСЛЫ И ИТАЛЬЯНСКИЕ МУЗЫКАЛЬНЫЕ ВЛИЯНИЯ}

Статья посвящена рассмотрению единственной фортепианной миниатюры М. Глинки итальянских лет (1830-1833 г2.). Указанные автором время и место сочинения раскрывают автобиографические смыслы пьесы, музыкального обращения к другу Е. Штеричу.

Ключевые слова: программная фортепианная миниатюра Глинки, автобиографические смыслы, романтическая тема дружеского общения, образы прощания, разлуки и воспоминаний.

...Друзья! Оставьте призрак славы, Любите в юности забавы И сейте розы на пути. О юность красная! Цвети!...

К. Н. Батюшков. Совет друзьям

...Но там, увы, где неба своды

Сияют в блеске голубом, Где тень олив легла на воды, Заснула ты последним сном...

А. С. Пушкин. «Для берегов отчизны дальной...» ...Скорбь и радость давних лет Отозвались мне, И минувшего привет Слышу в тишине...

В. А. Жуковский. Кмесяиу

«Прощальный вальс» - единственная фортепианная миниатюра, написанная М. Глинкой в годы итальянского путешествия (18301833 гг.). На фоне насыщенных приемами бравурной виртуозности крупных ансамблевых и фортепианных сочинений этого трехлетия - Большого секстета, «Патетического трио» и ряда парафразов с использованием оперного материала В. Беллини и Г. Доницетти ${ }^{1}$ - миниатюра «Прощальный вальс» выглядит едва ли не аскетично, являясь исключением из стиля глинкинских произведений ита-

\footnotetext{
${ }^{1}$ Как для камерных инструментальных составов, так и для фортепиано соло.
}

(С) Тимченко-Быхун И., 2014 
льянской поры ${ }^{1}$. Речь идет не только о крайне малом объеме пьесы (24-тактовый дважды повторенный период), что уже необычно для фортепианного письма Глинки этих лет, но и о том, что отсутствие технической исполнительской сложности миниатюры в сочетании с прозрачностью фактуры воспринимается как сознательный композиторский отказ в данном (и единственном!) случае от целого набора музыкальных средств, присущих всем остальным фортепианным пьесам времени пребывания в Италии.

«Прощальный вальс» написан в 1831 году. Ему предшествуют два крупных фортепианных сочинения - Вариации на тему из оперы «Анна Болейн» Г. Доницетти и Рондо на тему из оперы «Монтекки и Капулети» В. Беллини, на три последующих года задавшие основные композиционно-драматургические принципы глинкинской работы с заимствованным музыкальным материалом ${ }^{2}$. В итальянский период композитора интересуют крупные концертные формы, позволяющие ему как пианисту продемонстрировать востребованную европейским слушателем бриллиантную виртуозную технику, увлечь узнаваемыми оперными мелодиями, покорить фантазией необычной композиции и вариационно-импровизационного музыкального мастерства.

O пьесе «Прощальный вальс» в музыковедческой литературе практически ничего не написано. Ни в монографии Т. Ливановой и Вл. Протопопова [11; 12], ни в более новой книге О. Левашевой [10] вальс не рассматривается, то же можно сказать и о труде К. Зенкина [7]; в исследовании Е. Петрушанской о пьесе есть лишь отдельные упоминания [19] $]^{3}$. Однако именно пьеса «Прощальный вальс», во многом вырастая из принципов пианизма Глинки петербургских

1 Подобные наблюдения относятся и к одному из трех романсов, написанных в Италии, однако особенности музыкального языка романса «Венецианская ночь» прозрачность фактуры, ритмическая однородность, музыкальная статичность, т. е. особая «минималистичность» в выборе и использовании средств музыкальной выразительности как осознанный прием - обусловлены во многом поэтической образностью и «пастельностью» стихотворения И. Козлова. См. подробнее: [22].

${ }^{2}$ Оба сочинения относятся к жанру парафраза. Принцип использования в виртуозных инструментальных (в особенности фортепианных) сочинениях оперных мелодий был характерен для романтической эпохи. Европейская мода на парафразы оказала влияние и на русскую камерную музыку; такого рода сочинения Асафьев называет «попытками сохранить и запечатлеть в памяти, путем разного сорта «музыкальных репродукций», оставившие след впечатления от опер и концертов» [1, с. 210]. О фортепианных парафразах Глинки в контексте европейской музыкальной культуры см.: [22].

${ }^{3}$ Е. Петрушанская отмечает: «Изящные «полутени» гармоний сближают его с вальсом Грибоедова...» [19, с. 179]. 
лет, являет собою концентрацию автобиографических смыслов; ею начинается линия глинкинской программной фортепианной миниатюры - одна из наиболее значимых в области камерно-инструментальной сферы.

Ключом к пониманию автобиографичности пьесы становится редкий факт: «Прощальный вальс» - одна из немногих миниатюр Глинки, в которой точно указано время и место сочинения -15 июня 1831 года, Турин. В «Записках» Глинка замечает: «В начале июня я навестил Штерича в Турине, чтобы проститься с ним пред его отбездом 8 Германию на воды (курсив мой. - И. Т.)» [3, с. 45].

Необходимо заметить, что с Евгением Штеричем Глинку уже на тот момент связывало немало воспоминаний: их знакомство состоялось во время занятий Глинки с К. Майером в Петербурге в 1827 году, у которого музыкально одаренный Евгений также брал уроки фортепиано. Совместная принадлежность к исполнительскому искусству и сочинительству объединила молодых людей: Штерич стал одним из самых близких друзей Глинки в первые итальянские годы. Итальянский виток их дружбы начинается с совместного путешествия через Швейцарию в Милан, где Штерич остается ненадолго; «он должен был вскоре отправиться в Турин, быв причислен к нашему посольству при Сардинском дворе» - пишет Глинка [3, с. 40]. Однако дальше их встречи продолжаются: это посещения миланских театров, совместные слезы «умиления и восторга» при прослушивании итальянских романтических опер [3, с. 43], это знакомство Глинки по рекомендации Штерича с врачом Де Филиппи, сыгравшим впоследствии немалую роль в судьбе Глинки в итальянские годы, это общение «душа в душу» [3, с. 43], это и многочисленные попытки Глинки утешить Штерича, влюбленного в танцовщицу, против которой категорически была настроена его матушка, опасаясь за будущую карьеру сына. Удивительно ли, что первое итальянское сочинение, Вариации на тему «Анны Болейн» Г. Доницетти, Глинка посвящает Евгению Штеричу?

Навестив Штерича в Турине в июне 1831 года, Глинка вновь становится свидетелем «смешных и грустных сцен вместе» - «Серафима Ивановна была крайне раздражена на танцовщицу сына своего» [3, с. 45]; тогда он пишет «Прощальный вальс». Не упоминая в «Записках» о сочинении пьесы, Глинка обозначает лишь цель поездки: «проститься». Н. Загорный, приводя дату создания пьесы и фрагмент «Записок», справедливо констатирует: «Сопоставление этой запи- 
си с данными, приведенными в «Эоловой арфе» (Вальс был издан в журнале «Эолова арфа», № 6. - И. T.), раскрывает с полной достоверностью повод сочинения Вальса и смысл данного ему автором названия» [5, с. 422]. Столь редкий случай прямой связи личностнобиографического и творческого событий!

Итак, фортепианная пьеса - это обращение к другу, дружеское послание. Однако вальс - еще и прямой вариант творческого диалога': ведь сам Штерич был известен в музыкальном Петербурге именно как сочинитель вальсов. Например, в выпушенном Н. И. Павлищевым и М. Глинкой в 1829 году «Лирическом альбоме», наряду с сочинениями М. Глинки, Н. Павлищева, М. Виельгорского, М. Шимановской, был напечатан и вальс Е. Штерича (возможно, что «Прощальный вальс» это «итальянский» ответ Глинки на «российскую» миниатюру друга). Но если вспомнить, что Глинка встретится с Евгением еще лишь один раз, во время поездки в Неаполь в сентябре того же года, проведет с ним два дня в Генуе и простится навсегда («Это было последнее с ним свидание; он скончался в следующем году в Петербурге, вскоре по возвращении в Россию» [3, с. 46]), то название миниатюры приобретет чуть ли не метафизический смысл: вот уж поистине прощание ${ }^{2} .$.

Форма дружеского послания наполнена для Глинки романтическими смыслами: от мотивов дружбы в целом, одной из важнейших тем русской и западноевропейской литературы и эпистоляриев этого времени, когда общению между душами, породненными общими художественными устремлениями, придавался статус возвышенной исповедальности, до личностного к ней отношения композитора. «Настоящий культ интимной дружбы в России, как и в Европе, - пишет И. Кон, - появляется вместе с романтизмом. Почти все хрестоматийные образцы дружбы в русской литературе и жизни первой половины XIX в. (лицейские дружбы А. С. Пушкина

${ }^{1}$ Диалог на тему вальса был начат ранее: еще в 1829 году Глинка сделал транскрипцию Вальса Е. Штерича на тему из «Оберона» Вебера для флейты, двух кларнетов, двух валторн, трубы, тромбона, литавр, двух скрипок, баса [12, с. 362].

2 Этот факт прощания навек отмечает и Е. Петрушанская в монографии [19].

3 «Блажен, кому судьба друзей послала...» - так А. Пушкин выражает особую ценность настоящего душевного родства. Негодуя по поводу принятых правил дружеских отношений, Пушкин требовал искренности и от себя, и от близких: «Я хочу доказывать моим друзьям, что не только их люблю и верую в них, но и признаю за долг и им, и себе, и посторонним показывать, что они для меня из порядочных, перед которыми я не хочу и боюсь манкировать чем бы то ни было, освященным обыкновениями и правилами общежития» (цит по: [8, с. 162]). 
и Н. П. Огарева, взаимоотношения В. Г. Белинского и М. А. Бакунина и т. д.) имели отчетливо романтический характер. При этом нормативный канон дружбы и индивидуальные переживания сплошь и рядом переплетаются, накладываются друг на друга» [9]. Значимость для Пушкина дружеских отношений отмечает Д. Лихачев: «Дружба была вдохновительницей большинства его стихотворений, самых высоких переживаний. ...Даже его отношения с женшинами по большей части носили этот характер дружбы (я не говорю, что дружба вытесняла любовь, но нельзя видеть в этих отношениях только любовь, как стремятся многие)» [13, с. 211-263].

Своеобразный, романтический вариант дружбы с женщинами (в судьбе Глинки также были подобные платонически-доверительные отношения - на протяжении многих лет дружба с М. Задорожной ${ }^{1}$, общение с М. Щербатовой ${ }^{2}$ ) дополняется в эту эпоху и усилением эмоционального тонуса товарищеской дружбы между мужчинами. «Вместе с amitie amoureuse ${ }^{3},-$ пишет А. Н. Веселовский в книге, посвященной В. А. Жуковскому, - развилось особое чувство дружбы, также смешанное из любви и приязни и невольно вызывающее на сравнение с таким же психологическим явлением Ренессанса. «Нам нужен друг, чтобы мы сами себе нравились и сами собой наслаждались» - говорил Юнг; немецкие сентименталисты, начиная с

${ }^{1}$ В книге С. Тышко и С. Мамаева приводятся сведения о М. Задорожной (Кржисевич) из биографических исследований, посвященных Глинке: «ее называли «обаятельной женщиной», «близким другом», «одной из очень милых сердцу Глинки женщиндрузей»...». Однако авторы книги подчеркивают иные, более существенные грани их отношений, вообще редких между мужчиной и женщиной и исключительных в судьбе композитора: «...В жизни Глинки не было женщины, отношения с которой были бы столь долгими и прочными, были бы освещены таким взаимопониманием, и они, конечно, были выше светской «болтовни» и старческого «бегства от скуки»» [24, с. 126]. «...Их переписка, - подчеркивают С. Тышко и С. Мамаев, - продолжалась почти до самой смерти композитора» [24, с. 126].

${ }^{2}$ И в этих отношениях незримо присутствует облик Е. Штерича: княгиня М. Щербатова была его старшей племянницей. «Я был у них как домашний, нередко обедал и проводил часть вечера», - вспоминает композитор; эти воспоминания относятся к 1838 г. И далее: «Иногда получал от молодой княгини-вдовы маленькие записочки, где меня приглашали обедать с обещанием мне порции луны и шубки... Она располагалась на софе, я на креслах возле нее; иногда беседа, иногда приятное безотчетное мечтание доставляли мне приятные минуты. Мысль об умершем моем друге достаточна была, чтобы удержать мое сердце в пределах поэтической дружбы (выделено мной. - И. Т.) [3, c. 86]. Комментарии излишни. Добавим лишь, что многие современники отмечали ум и особое обаяние княгини, в нее, как известно, был влюблен М. Лермонтов.

${ }^{3}$ Влюбленная дружба (фр.). 
Клопштока, лелеют это чувство, ревнивое, тревожное и взыскательное, как будто дело идет о любимой женщине. В литературе являются Позы и Дон Карлосы, Ксаверы и Кронгельмы (Миллер и Ф. Штольберг в романе Миллера «Сигварт»), в жизни - дружба Нойффера и Гельдерлина, а в период романтиков - Тика и Ваккенродера, Фридриха Шлегеля и Новалиса и др.; с примерами из древности: Давида и Ионафана, Ореста и Пилада, Низа и Эвриала, Ахилла и Патрокла» [2]. Влюбленная дружба - романтический феномен - соединяет обе грани: высокого духовного тонуса товарищеской близости мужчин, особого художественного родства, и поиска в женщине друга, поэтизирующего отношения.

Тема дружбы в варианте духовной и душевной родственности один из литературных лейтмотивов писем и «Записок» Глинки, не менее важная составляющая его жизненного мира, чем любовь и влюбленность. Глинка-мимоза, как его называли друзья, всегда нуждался в среде понимающей и одобряющей. Эта область жизненного мира Глинки на много лет отдана братии во главе с Н. Кукольником. Достаточно вспомнить, что именно братии, наравне с близкими родственниками, композитор поверяет свои жизненные невзгоды и переживания во время болезненного развода ${ }^{1}$.

Как Глинка ценит дружеское общение ${ }^{2}$, как нуждается в нем, в особенности в молодые годы, ясно не столько из «Записок», сколь-

${ }^{1}$ В жизни Глинки, в его литературных и музыкальных текстах мы видим подобные черты дружеского общения, вдохновляющего, но и вдохновенного, обращающего саму повседневную жизнь в поэзию, а поэзию - в разговор, освященных товариществом, поднимающих обыденность до самых высоких сфер искусства. Эта тема литературных текстов Глинки становится частью европейского романтического диалога, происходящего между «поверенными душами», тем самым он соединяет автобиографические мотивы с художественной литературой. Братией Глинка называл «общество, образовавшееся еще с 1835 или 1836 года у Кукольника и слившееся потом в одну искреннюю, добрую, дружную семью» [3, с. 90]. Метафора «семья» символична: братия становится для Глинки заменой семейного уюта, к которому композитор стремился всегда, но обрести не сумел. В. Стасов пишет: «Натура Глинки всегда нуждалась, чтоб такой энтузиазм поднимал на своих крыльях его вдохновение: для того чтобы творить высокое... чтобы воплощать в формах искусства моменты своей собственной жизни, Глинке необходимо было стоять центром всеобщего ожидания и восторженности...» [20].

${ }^{2} \mathrm{C}$ темой дружеского общения в жизни Глинки связано творчество в музыке, литературе, живописи (в последнем - Глинка выступает не автором, а одни из главных героев). Так, рисунки, созданные его друзьями - Н. Степановым и К. Брюлловым, - изображают композитора в кругу друзей в шаржированном, но и лирическом ключе: это творческие и повседневные ситуации. И в музыке Глинки тема дружеского общения отразится в разных жанрах - хоровом, камерно-вокальном, камерно-инструментальном. 
ко из его писем. Вот строки С. Шевыреву от 10 ноября 1831 года из Италии: «Твоя дружба так разогрела мое почти охладевшее сердце, что я снова воскрес для изящных и высоких впечатлений» [4, с. 38], или В. Ф. и А. Г. Ширковым от 29 марта 1841 года из Петербурга: «Приятелей много, но они склонны издеваться над моими страданиями, нежели понимать и утешать меня, - ты один вполне постигал меня; но тебя нет здесь, и огромная наша столица теперь пустынна для меня, как беспредельная украинская степь» [4, с. 123]; даже если тон Глинки несколько преувеличенно эмоционален, слегка шутлив, здесь нет иронии.

Дружба рано ушедшего из жизни Андрея Тургенева с В. Жуковским становится одним из образцов романтического сердечного родства, окрашенного сентиментализмом: «Поэзия и дружба, - писал Тургенев Жуковскому, - поэзия в уединении с друзьями - вот утопия западных и наших сентименталистов; в одиночестве не воспитать гуманного чувства, сердце возделывается в взаимодействии одинаково настроенных людей» [2]. Дружба становится жизненно необходимым фоном для творчества, вдохновения, самого существования, неслучайно замечание А. Н. Веселовского о том, что многосторонне одаренный А. Тургенев «свою литературную деятельность... всегда прислонял к дружескому кружку» [2]. В раннеромантическую пору еще сильно влияние сентиментализма, ощутимо выраженного в творчестве Жуковского первой трети века; веяния этого художественного направления проявляются и в мышлении Глинки, поскольку отвечают его мировосприятию ранних лет. Возможно, поэтому товарищеские чувства выражаются в его музыке ностальгически: это почти всегда образ прощания ${ }^{1}$.

«Прощальный вальс» становится своеобразной формой «музыкального письма» Глинки другу; его музыкальный язык интонационно связан с декламационно-речевым началом. Ю. Лотман обрисовывает суть письменного общения в русской культуре XVIII-XIX вв.:

\footnotetext{
${ }^{1}$ Дружба со Штеричем, длившаяся всего несколько лет, становится одним из мотивов нескольких эпизодов «Записок» Глинки. Такая долгая память скорее исключение, чем правило для романтического времени. Так, Ю. Лотман подчеркивает поразительную «способность забывать», бывшую «оборотной стороной быстрого исторического движения», при которой «вчерашний день проваливается в небытие». И далее: «Друзья - а Андрей Тургенев прожил свою короткую жизнь в обстановке пламенной дружбы - не выполнили даже простого дружеского долга: намерение собрать и издать произведения покойного поэта так и не было осуществлено и о нем вскоре забыли» [16, c. 349].
} 
«... Пишуший имел перед собой как бы двух адресатов. Он писал своему другу или возлюбленной и одновременно писал сам себе... Карамзин сказал... о своем герое, что он никогда не перестанет... «наслаждаться собой в сердце друга» [15, с. 459]. Слова Карамзина передают суть эпистолярного дружеского общения XIX в., одновременно помогая раскрыть смыслы миниатюры Глинки - виртуально отправленного музыкального послания.

«Прощальный вальс» написан в тональности соль мажор ${ }^{1}$. Форма миниатюры - дважды повторенный период из шести предложений, каждое из которых делится на две фразы. Два первых предложения повторяются в точности; третье вносит мелодическое обновление: одна из фраз представляет собой два звена секвенции с отклонением в ля минор, вторая - в ми минор, с возвращением в основную тональность. Здесь в заключительном предложении появляется минорная окраска; несмотря на преобладание мажора, образ пьесы вовсе не идиллический: это светлая грусть.

Миниатюра представляет собой необычный жанровый синтез: это не только вальс, но и романтическая прелюдия, в основе которой лежит жанр вальса (принцип, который напоминает шопеновские прелюдии, опирающиеся на ведущий жанр в сочетании с отдельными признаками еще нескольких). В основу движения миниатюры положен принцип прелюдирования, который преобладает над вальсовостью, совмещая мелодическое кружение вальса с ритмической остинатностью мелодики, тормозящей танцевальный порыв. Ровное вальсовое кружение мелодии, выстроенной по принципу скрытого двухголосия, в сочетании с ритмически столь же остинатным аккомпанементом (бас - два аккорда) в достаточно необычной форме реализует характерное глинкинское стремление к сочетанию антиномий. Этот жанровый синтез дает Глинке возможность соединить два противоположных начала: беззаботность и легкость вальсового кружения, субъективность эмоции с преодолевающим танцевальность

\footnotetext{
${ }^{1}$ Семантика тональностей фортепианного творчества Глинки - тема, практически не исследованная. Тональность соль мажор в области глинкинского пианизма связана, как правило, с танцевальной сферой. Так, два фортепианных сочинения зрелого периода (1839 г.) танцевальной природы - Вальс и Контрданс - написаны в этой тональности, что, возможно, связано с индивидуальным «удобством» соль мажора для Глинки-исполнителя. Вообще тональность соль мажор достаточно часто встречается в его фортепианной музыке разных лет; в ней, кроме названных, написаны Мазурка (изд. в 1829 г.), Французская кадриль (изд. в 1829 г.), Кавалерийская рысь (1829 г.), Баркарола (1847 г.), Андалузский танец (1855 г.).
} 
прелюдийным флером грусти, в то же время объективизирующим эмоциональный строй пьесы. То есть оказывается, что в программе пьесы смысловой центр смещен со слова «вальс» на эпитет «прощальный», который и определяет эмоциональный тонус сочинения. Очевидно, что этот ранний пример скрытой программности, реализованной через жанровые синтезы текста музыкального, вступающего в диалог с текстом вербальным, в своей интенции направлен к линии глинкинских фортепианных сочинений подобного рода: «Вальсуфантазии», ноктюрну «Разлука», пьесам фортепианного цикла последнего десятилетия «Привет Отчизне» ${ }^{1}$.

Пьеса выдержана в едином образе; мелодические фразы интонационно родственны. В начале каждой фразы повторяется мотив восходящая речевая интонация из затакта от третьей к пятой ступени: это обращение к собеседнику, одна и та же просьба. В верхней линии скрытого двухголосия, несмотря на ее обшую ритмическую однородность, создается ощущение постоянного синкопирования, сближающее ее с неравномерностью речевого произнесения, которое также будто тормозит движение вальса.

А теперь вернемся к вопросу о чертах «итальянского» в вальсе Глинки. Они здесь выражены достаточно опосредованно, не на уровне осознанного заимствования, а, скорее, едва ощутимого воздействия отдельных музыкальных впечатлений. Уже начальная мелодическая фраза выстроена в сходстве с излюбленным принципом строения знаменитых оперных мелодий Беллини, которые, начинаясь с нескольких звуков, постепенно как бы раскручиваясь, охватывают все больший диапазон. Это не удивительно: слышанные оперные мелодии Беллини могли дать такой своеобразный отголосок в мелодике интонационно чуткого русского композитора. Однако мелодия вальса Глинки скорее не белькантовой природы: она почти лишена украшений и, в сравнении с его изысканно орнаментированными сложными группами мелизматики мелодиями вариационных циклов этих лет, выглядит чуть ли не аскетично. Более того, мелодия по природе не вокальна, а инструментальна; отчасти она напоминает знаменитую мелодию вальса Грибоедова ${ }^{2}$, изложенную ровны-

${ }^{1}$ Автобиографические и художественные смыслы четырех пьес цикла реализованы посредством диалогического взаимодействия музыкального и вербального текстов. См. об этом статью автора: [21].

2 Это сходство проявляется лишь на уровне фактурном, композиционном, но не образно-смысловом. 
ми восьмыми с затейливым кружением и строящуюся на скрытом двухголосии, однако сходство на этом заканчивается: глинкинский вальс, в отличие от грибоедовского, соединяет противоположные тенденции к полетности и тормозящей, объективизирующей ее повествовательности.

Идиллически-просветленное настроение, присущее ранним петербургским пьесам Глинки - образности Вариационного цикла на тему Моцарта, Ноктюрну (1828 г.), отличает «Прощальный вальс» лишь отчасти. Его образ лишен беззаботности; здесь присутствует оттенок печали, скрытой тревоги: неслучайно пять фраз из шести, составляющих основу вальса, начинаются одной и той же восходящей интонацией от третьей к пятой ступени, настойчиво повторяющей это обращение; окончания фраз гаснут в нисходящих интонациях по звукам тонического квартсекстаккорда.

В этом вальсе, созданном в период пика увлечения Глинки итальянской музыкальной культурой, мало итальянского. Возможно, потому, что этот диалог, во многом интимного, «камерного» характера, происходит условно не в географически-пространственном или культурном измерении, а во временно́м, или, точнее, вневременно́м, продолжением давно начатого и не законченного разговора. Удивительно, но этот разговор будет продолжаться и в последние годы жизни Глинки воспоминаниями о друге юности на страницах «Записок»; не исключено, что и в иных его музыкальных сочинениях разных лет.

Уникальность музыкального языка «Прощального вальса», существующего особняком среди сочинений итальянского трехлетия, повидимому, обусловлена художественно-биографической ситуацией его возникновения: смысловая близость музыкальной миниатюры жанру письма определяет его исключительность. Ведь письма личного содержания у Глинки всегда отличались характерным сочетанием речевой естественности, простоты слога и безыскусственности. «... Друг - это зеркало, обладающее высокой индивидуальностью, и в нем высвечивается то, что в других зеркалах не находит себе отражения», - замечает Ю. Лотман, подчеркивая, что система «отражений» в дружеской переписке способна воспроизвести «бесконечное приближение к неповторимой индивидуальности» ${ }^{1}$ [14, с. 505] - «к себе через другого и к другому через себя» [14, с. 506].

\footnotetext{
${ }^{1}$ В статье эти слова Ю. Лотмана адресованы П. Вяземскому [14, с. 505].
} 
Область фортепианной музыки, - наряду с камерно-вокальной, - для Глинки всегда оставалась творческой сферой, близкой дневниковым записям, интимным высказываниям, раскрывающим мир души. Об этом свидетельствуют автобиографические факты, подтверждающие случаи сочинения фортепианных миниатюр в результате эмоционального впечатления-переживания («Детская полька»), непосредственного выражения мимолетного чувства («Мазурка, сочиненная в дилижансе»), дружеского обращения («Прощальный вальс»), любовного послания («Вальс-фантазия») и т. д. Конечно, смысло-образы названных сочинений, созданных во многом под непосредственным впечатлением, перерастают семантику автобиографичности и выходят на уровень смыслов общекультурных. Автобиографичность в творчестве В. Жуковского неоднократно отмечалась исследователями; слова Г. Гуковского можно спроецировать и на особенности мышления Глинки: «...Образ-характер героя и носителя поэзии Жуковского был образом его самого, был автобиографичен. ...Жизнь Жуковского стоит за его стихами, хотя именно только за ними, а не $в$ них. ...О чем бы ни писал Жуковский, все звучало как страницы его романа, реального и жизненного» [6, с. 139-140]. «В любой творческой работе выражены основные концептуальные критерии одаренной личности, ее художественное кредо» (выделено мной. - И. Т.), - замечает С. Махлина [18, с. 161]. В миниатюре «Прощальный вальс» композиторское художественное кредо выражено непосредственно и по-юношески открыто; в такой мере - в первый и последний раз.

Тема прощания в творчестве Глинки связана с разлукой с друзьями, а в последнее десятилетие и с образами собственного прошлого. Вспомним его «Прощальную песнь» на слова Н. Кукольника «Простите, добрые друзья» (1840) и в целом вокальный цикл «Прощание с Петербургом», который обращен не столько к образам города, сколько к кругу друзей. Или фортепианный цикл «Привет Отчизне» (1847 г.), ностальгические образы которого обрашены в прошлое: «привет» понимается не как приветствие, а как прощальный, «последний привет». Тема прощания продолжается и в двух сочинениях зрелых лет - «Вальсе-фантазии» и Ноктюрне «Разлука» (1839 г.): она воплощена в названии и образности ноктюрна, в мелодической романсовой интонации элегического настроения первой темы вальса. «Прощальный вальс» открывает тему разлуки, одну из знаковых в жизненной и творческой судь- 
бе Глинки ${ }^{1}$. И в этом смысле обращение композитора к инструментовке ноктюрна И. Гуммеля «Память дружбы» в 1854 году [12, с. 369] даже символично.

Диалог с собственным сочинением, разъединенный во времени скорее правило, чем исключение в творчестве Глинки: его поздние сочинения часто имеют тематические и образные связи с ранними, и совсем не обязательно - на общей жанровой почве. Подобная черта творческого мышления отмечалась и в поэтическом стиле Пушкина: «...Поэзия поэта имеет свою собственную память. Поздние стихи «помнят» о ранних», - замечает Д. Лихачев [13, с. 211-263].

Программные фортепианные пьесы зрелого периода Глинки, кульминация песенно-романсовой, элегической и драматической сфер его пианизма (Ноктюрн «Разлука», «Вальс-фантазия», «Воспоминание о мазурке», «Баркарола», «Молитва», «Шотландские вариации»), - наполнены памятью ранних миниатюр, ностальгической образностью расставания и воспоминаний. Но эта печаль светла: она соединена с грацией танца, пейзажной лирикой или романсовостью, она уравновешена утешением и смирением. В этом смысле вслед за В. Жуковским Глинка мог бы повторить: «О милых спутниках, которые наш свет / Своим сопутствием для нас животворили, / Не говори с тоской: их нет, / Но с благодарностию: были» [23, с. 45].

\section{СПИСОК ЛИТЕРАТУРЫ}

1. Асафьев Б. Камерная инструментальная музыка / Б. Асафьев // Русская музыка XIX и начала XX века. - Л. : Музыка, 1968. - С. 209-264.

2. Веселовский А. Н. Поэзия чувства и «сердечного воображения» / А. Н. Веселовский. - СПб., 1904 [Электронный ресурс]. - Режим доступа: http://dugward.ru/library/gukovskiy/veselovskiy_gukovskiy.html

3. Глинка М. И. Записки / М. И. Глинка ; подготовил А. С. Розанов. - М. : Музыка, 1988. - 222 с.

4. Глинка М. И. Полное собрание сочинений. Литературные произведения и переписка / М. И. Глинка ; подготовили А. С. Ляпунова и А. С. Розанов - М. : Музыка, 1975. - Т. ІІА: Письма 1822-1853. Документы. -415 с.

5. Глинка М. И. Полное собрание фортепианных сочинений / М. И. Глинка ; ред., вступ. ст. и ком. Н. Н. Загорного. - Л., 1952. - T. IV. - 442 с.

${ }^{1}$ Тема разлуки и потерь до крайности обострена у Тютчева, что связано с событиями его личной судьбы. Ю. Лотман подчеркивает: «Отождествление небытия и «где-то» обусловило то болезненное чувство, которое Тютчев связывал с разлукой» [17, с. 568]. В стихотворении «В разлуке есть высокое значенье...» Ю. Лотман отмечает равнозначность «высокого значенья» разлуки «высокому значенью» смерти [17, с. 569]. 
6. Гуковский Г. А. Пушкин и русские романтики. / Г. А. Гуковский ; [редактор С. Лакшина]. - М. : Художественная литература, 1965. - 356 с. [Электронный pecypc]. - Режим доступа: http://feb-web.ru/feb/classics/critics/ gukovsky_g/guk/guk.htm

7. Зенкин К. В. Фортепианная миниатюра и пути музыкального романтизма / К. В. Зенкин. - М. : Московская государственная консерватория им. П. И. Чайковского, 1997. - 415 с.

8. Исхаков Х. И. Пушкин и религия / Х. И. Исхаков. - М. : Алгорит, 2005. $-624 \mathrm{c}$.

9. Кон И. С. О русской дружбе / И. С. Кон / Центр дистанционного образования «Элитариум» (Санкт-Петербург), 2015 [Электронный ресурс]. - Peжим доступа: http://www.elitarium.ru/2005/02/22/o_russkojj_druzhbe.html

10. Левашева О. Е. Михаил Иванович Глинка: в 2 т./ О. Е. Левашева. М. : Музыка, 1987. - Т. 1. - 381 с.

11. Ливанова Т. Глинка. Творческий путь: в 2 т. / Т. Ливанова, Вл. Протопопов. - М. : Государственное музыкальное издательство, 1955. - Т. 1. $404 \mathrm{c}$.

12. Ливанова Т. Глинка. Творческий путь: в 2 т. / Т. Ливанова, Вл. Протопопов. - М. : Государственное музыкальное издательство, 1955. - Т. 2. $380 \mathrm{c}$.

13. Лихачев Д. С. Заметки о русской литературе // Русская культура / Д. С. Лихачев. - М., 2000. - С. 211-263 [Электронный ресурс]. - Режим доступа: http://likhachev.lfond.spb.ru/articl100/class_lit/Literatura/zametky.pdf

14. Лотман Ю. М. Аутсайдер пушкинской эпохи / Ю. М. Лотман // О поэтах и поэзии. - СПб. : Искусство-СПБ, 2001. - С. 505-511.

15. Лотман Ю. М. Воспитание души. Воспоминания. Беседы. Интервью. В мире пушкинской поэзии (сценарий). Беседы о русской культуре. Телевизионные лекции / Ю. М. Лотман. - СПб. : Искусство-СПБ, 2005. - 624 с.

16. Лотман Ю. М. Поэзия 1790-1810-х годов / Ю. М. Лотман // О поэтах и поэзии. - СПб. : Искусство-СПБ, 2001. - С. 324-372.

17. Лотман Ю. М. Поэтический мир Тютчева / Ю. М. Лотман // О поэтах и поэзии. - СПб.: Искусство-СПБ, 2001. - С. 565-595.

18. Махлина С. Семиотика культуры и искусства: Словарь-справочник в двух книгах / С. Махлина. - 2-е изд., расшир. и испр. - СПб. : Композитор СПб., 2003. - Кн. 1. - 264 с.

19. Петрушанская Е. М. Михаил Глинка и Италия. Загадки жизни и творчества / Е. М. Петрушанская. - М. : Издательский дом «Классика-XXI», 2009. - 448 с. : ил.

20. Стасов В. В. Михаил Иванович Глинка / В. В. Стасов // Избранные сочинения: в 3 т. / [Редколлегия: Е. Д. Стасова, С. К. Исаков, М. В. Доброклонский, А. Н. Дмитриев, Е. В. Астафьев]. - Т. 1. : Живопись. Скульптура. Музыка. - М. : Искусство, 1952 [Электронный ресурс]. - Режим доступа: http://az.lib.ru/g/glinka_m_i 
21. Тимченко-Быхун И. А. Диалог музыкального и вербального текстов смоленской фортепианной тетралогии М. И. Глинки «Привет Отчизне» и его художественно-биографические смыслы / И. А. Тимченко-Быхун // Київське музикознавство. - Київ: Київський інститут музики ім. Р. М. Глієра, 2014. Вип. 34. - С.72-86.

22. Тимченко-Быхун И. А. Фортепианные парафразы М. И. Глинки: стилевые процессы в контексте межнациональных взаимодействий : дис. ... канд. искусствоведения / И. А. Тимченко-Быхун. - К. : НМАУ им. П. И. Чайковского, 2007. -228 с.

23. Три века русской поэзии / [сост. Н. В. Банников]. - 3-е изд. - М. : Просвещение, 1986. - 750 с.: ил.

24. Тышко С. В. Странствия Глинки. Комментарий к «Запискам»: в 3 ч. / С. В. Тышко, С. Г. Мамаев. - К., 2000; переиздание: К. : Радуга, 2005. - Ч. 1: Украина. - 214 с.

Тимченко-Бихун І. Перша програмна мініатюра М. Глінки «Прощальний вальс»: автобіографічні смисли та італійські музиині впливи. Стаття присвячена розгляду єдиної фортепіанної мініатюри М. Глінки італійських років (1830-1833 рр.). Указані автором час та місце створення розкривають автобіографічні смисли п’єси, музичного звернення до друга Е. Штеріча.

Ключові слова: програмна фортепіанна мініатюра Глінки, автобіографічні смисли, романтична тема дружнього спілкування, образи прощання, розлуки та споминів.

Tymchenko-Bykhun I. The first program miniature of Glinka «Farewell waltz»: autobiographical meanings and Italian musical influence. The article is devoted to the study of the single piano miniature by M. Glinka of the Italian years (1830-1833). The period and place of composing, mentioned by the author, reveal the autobiographical meanings of the play, the musical address to the E. Shterich, the friend.

Keywords: program piano miniature of Glinka, autobiographical meanings, romantic theme of companionship, images of farewell, absence and memories. 